UDC 378.147

DOI https://doi.org/10.32840/1992-5786.2021.74-2.35

S. V. Zhurkina

Senior Lecturer at the Foreign Languages Department National University of Pharmacy

I. V. Kolyada

Senior Lecturer at the Foreign Languages Department National University of Pharmacy

\title{
PECULIARITIES OF HISTORICAL AND PEDAGOGICAL ASPECTS OF INSTITUTIONAL TRANSFORMATIONS IN US HIGHER EDUCATION
}

The history of the tutorial system implementation into American Universities, the influence of the British tutorship on the development of the American higher education have been scrutinized in the article. The article considers the history of the introduction of the tutorial system in American universities, analyzes the impact of the British tutorial system on the development of US higher education.

The teaching method of higher education, when students are taught individually or in very small groups of two or three people, has developed and transformed into the establishment of a tutorial system at the Universities of Oxford and Cambridge. This model of teaching has existed in Oxford since the 11th century, and the role of tutors was documented in the 15th century, when the tutors at Oxford University were described as responsible for the behavior and training of their younger colleagues. Thus, it should be noted that the tutorial system is a model of interaction between a tutor and students and it has a long history.

It is important to emphasize the fact that unlike the standard ideas of a teacher who could use different kinds of influence on a student to improve his achievements, namely: physical or moral punishment, you must remember that the Oxford tutor will always be on the student's side, he or she will tend to see how the tutor will do his or her best to push the student to search in the right direction, or to suggest what to do in order to achieve the best learning outcomes. The role of the tutor is the role of a fellow teacher, who should provide individual advice during regular weekly meetings and a very important point in the tutoring system is the fact that the tutor and students had the opportunity to meet and communicate in a less formal environment, which allowed students to be more involved in studying process and helped to create friendly relations between them.

In recent years, the structure and content of higher education in our country have undergone significant changes as a result of the integration of the national education system into the European educational space. It is necessary to reform the education system in all its parts. First of all, this applies to higher education, which must provide society with highly qualified specialists in various fields. Of real scientific and practical interest is the study of the experience and work of tutors in Great Britain and the United States in order to creatively use it in higher education in Ukraine.

Key words: tutorial system, tutorship, tutor, tertiary education, reforms in the University education, teaching method.

Formulation of the problem. For the time being, the structure and content of tertiary education in our country have undergone some significant changes as a result of the integration of the national education system into the European Educational Space. Reforming the education system at all levels is necessary. First of all, this idea applies to higher education, which should provide society with highly qualified specialists in various fields. A real scientific and practical interest is the study of the experience and work of tutors in Great Britain and the United States in order to use it creatively in tertiary education in Ukraine.

The topicality of this issue has led to a study on "The tutorial system in higher education in the UK and USA".

Analysis of recent research and publications. As the study of scientific literature has shown, only in some works on the theory and practice of higher education in the UK and the United States, there are developments in certain aspects of the organization of tutorials in these countries. Various aspects of the British and American models of higher school have been analyzed in the works of A. Barbaryga, N. Fedorova, T. Georgieva, V. Yelmanova, I. Martsinkovsky, L. Suprunova and A. Ivanova, L. Filipova, N. Nikandrova and others. The issue of studying the introduction of the Oxbridge tutorial model in the universities of the United States and the comparative analysis of the English and American tutoring models in the works of domestic scholars has been studied insufficiently.

The purpose of the article is to analyze the changes in the system of higher education in the United States since the end of the 19th century to the 1970s, the introduction of a tutorial system in American universities, and the influence of the British tutorial system on American tertiary education. 
Presenting the main material. It is essential to mention the fact that higher education in the United States began to undergo major changes between the 1860s and 1910s. Supporters of some tertiary education reforms in the United States agreed with Wilson, who believed that college education should help students to develop themselves intellectually and spiritually. In this regard, the relationship between students and teachers played a very important role, which had to move to a qualitatively new level. The teacher had not only to advise students formally in the learning process, but also in an informal setting, as far as possible, to share their life experiences with students, to interest them in their subject.

It is believed that the main purpose for the lack of close contact between a student and teacher in the classrooms of American universities is considered to be the influence of German higher education. Scientists, who are representatives of this school "felt disgust for the teaching process and looked at students as some obstacles" [12]. Progressive teachers felt that every college student "should have at least one fellow teacher, someone who will observe his studies, will know about family circumstances, how the student learns, what are his prospects, abilities and shortcomings" [ibid. itself].

Beginning in the late 1890s, Cambridge and especially Oxford became the examples of the existence of such a fellow teacher. Each student was attached to a tutor who provided individual counseling during regular weekly meetings. In addition, students were asked to write essays based on the materials read and studied, which were discussed during tutorials. Except for tutorials, students and teachers were able to meet and socialize in a less formal atmosphere due to the fact that most faculty members lived in colleges. John Corbin, followed by Frank Bowles, referring to the experience of English colleagues, came to the conclusion that undergraduate student body should be divided into more manageable groups, each under the supervision of its own dean [4].

The President of Swarthmore College, from 1921 to 1940 , Frank Aydelotte was one of the supporters of the importing English tutorial system to American universities. Beginning in 1910, while still teaching English at Indian University, he wrote a series of articles in which he enthusiastically described the teaching system at Oxford. The main emphasis of Aydelotte was on the responsibility of each student for self-education with the active help of a tutor [2].

It is important to point out that traces of changes in the higher education system in the United States in the late 19th and early 20th centuries can be traced to the example of the largest American higher education institution, we mean the Harvard University. For instance, Edwin Slosson noted that students were in need for more attention from teachers and especially those who are officially appointed counselors. He stated that at Harvard the counselor should introduce freshmen to their responsibilities, help them to adapt to the university, but in reality these meetings were purely formal and no more personal than providing information on the train schedules at the railwaystation.

In 1904, Harvard graduate John Fogg Twombly offered a prize to the middle and high school students for the three best essays on the topic "The Possibility and Necessity of Establishing a Modified English College System at Our Large Universities, with Particular Reference to Harvard". The winning essay, by Henry Putnam Pratt, was published in the Harvard Graduate's Magazine, along with Twombly's commentary. Both authors noted the need to reorganize the university, requiring the college to be divided into six "halls", each of which would house about two hundred students and six tutors selected from the university's faculty. It was assumed that the division into "halls" would take into account the academic interests of students and, therefore, tutors will be selected depending on the subjects they teach. Each week, the student will attend about ten lectures by university professors and six to eight conferences or "section meetings" in the "hall" conducted by the tutor [13].

The Rector of Princeton University, from 1902 to 1910 , W.Wilson noted that self-education plays an important role in the entire educational process. $\mathrm{He}$ underlined the fact that students should acquire knowledge independently and the teacher should act as a mentor. To him, teaching was a matter of "intellectual companionship and guidance provided by those more mature and experienced to those less so" [9]. W. Wilson mentioned that the idea to reform Princeton University came to him in 1897 after visiting Oxford [3]. First of all, the curriculum underwent serious changes. Secondly, an important point of the reforms was to modify a tutorial plan, called the preceptorial system.

The Princeton preceptorial plan was a modified form of the Oxford Tutorial system, which aimed to introduce teaching methods and direct personal contact between teachers and students of the small college into the great university. The importing of such a system required the introduction of a new position in the teaching staff. This new position was called a preceptor whose primary responsibility was to engage students in individualized intellectual academic communication, such as what Wilson observed at Oxford. According to the plan, junior- and senior- level students met each week with a preceptor in tutorials, the purpose of these classes were to discuss selfdeveloped additional literature on the topics of the lectures. Wilson noted that preceptors were to be teachers who have a reputation as gentlemen, have established themselves as clubable people, whose personal communication skills will help them influence the intellectual development of young people. 
The cornerstone of this reform was the lack of funding, but Wilson was able to convince the trustees, and in 1905 they officially established the title "preceptor". Forty-five teachers held these positions, twenty of whom had already worked at Princeton and others had moved from other high schools. Thirty-seven preceptors had doctoral degrees. These changes convinced Wilson that direct contact between young people and more experienced peers was important in the learning process.

The preceptorial plan existed in Princeton even after Wilson resigned as the Rector in 1910. But as early as 1908, Abraham Flexner expressed doubts about this system, which were eventually confirmed. Preceptors were burdened with reading many courses, and they barely had time for direct individual communication with students. The system, therefore, did not promote the development of individual learning, which was considered the main goal. And in 1925 the position of the preceptor was abolished at the university. But reforms at Princeton were important for the introduction of a tutor position in higher education in the future. on the money of Yale University [11].

Lowell insisted on a system of tutoring, as it provided for the stimulation of the mental activity of "apathetic Harvard students" and, consequently, a significant increase in their level of knowledge. At the initiative of the Rector, the faculties of history, social sciences and economics in 1912 introduced the final general examinations and the tutorial system. Starting with the second year, each student was assigned a tutor in the profile discipline. This tutor worked with the student until the last year of studies, preparing him for the exam. From 1919 to 1924, all faculties, except for chemical and technical ones, introduced final exams and tutorials.

We have to point out that the structure of the faculties of the American university prevented the copying of the Oxbridge model of communication between a student and a teacher. The appointments of tutors, the value of the tutorial system at different faculties were different. In some faculties, senior students were appointed the tutors, in others, all teachers acted as instructors; some of them considered the tutorial system to be the main form of education, others did not pay big attention to it. Although, Lowell tried to create an "Oxbridge ideal at an American university", Harvard students often encountered "inexperienced and uninteresting tutors".

Some Harvard University professors have tried to consult with colleagues at Oxford about the "mechanisms of the tutorial system". In 1924, after Harvard's English faculty decided to introduce a tutorial system, two university professors were sent to Oxford to study the system in action. But they were able to attend an English university only in the summer and therefore were not able to fully observe the tutorial system in action. Describing the visit, Perkins noted that Oxford tutors were surprised by the goals of the tutorial plan at Harvard. According to Perkins, we can see that the American concept of tutorship was very different from the English one [10]. Similar criticisms of tutorship in Oxbridge in the 1920s were made by James Rowland Angell. In 1921, he became the Rector of Yale College, and it was he who came up with the idea of "informal contact between students and faculty" and the introduction of a tutorial system.

In order to study the experience of his English colleagues, in 1927 Angell visited Oxford, Cambridge and other English universities. He observed the relationship between students and tutors and concluded that they are reduced to living in the same college and having dinner at the same table. According to Angell, a tutor should be "an interesting person with organizational skills, with the ability and desire to pass on their experience to young people, a real teacher" [1]. During the 1930s and 1970s, Harvard's tutorial system was not as effective as expected. Alex Duke noted that the main reason for this was that the positions of tutors were mostly held by seniors. In addition, the students themselves did not consider working with tutors the main thing in their studies, because there was a very small number of really qualified tutors [5]. Later, in the 1960s and 1970s, there were also attempts at the University of Santa Cruz to introduce a tutorial system. But tutorials were large enough for this type of training and last but not the least, few of them knew how to conduct such classes.

Conclusions and prospects for further research. Thus, the importing the Oxbridge model of education to American universities was defeated, although it significantly influenced the development and formation of the higher education system in the United States. An American tutor is usually a senior or a young teacher who is responsible for advising a student on the study of certain subjects and the organization of university studies. A tutorial has not become a major component of higher education in the United States. The study of the content and forms of tutor activity in American universities allows adapting the positive experience of organizing tutorial activities in educational institutions of Ukraine. These issues should be promising in further research.

\section{References:}

1. Angell James Rowland. American Education: Addresses and Articles. New York : Books for Universities Press, 1970. P. 260-262.

2. Aydelotte Frank. Oxford Stampand Other Essays: Articles from the Educational Creed of an American Oxonian. New York : Oxford University Press, 1917. P. 5-6.

3. Baker, Ray Stannard. Woodrow Wilson: Life and Letters. Garden City, N.Y. : Doubleday, Page, 1939. P. 215. 
4. Corbin John. American at Oxford. Boston : Houghton - Mifflin. 1902. P. 302.

5. Duke Alex. Importing Oxbridge: English residential colleges and American universities. New Haven; London : Yale Univ. Press, 1996. P. 119-175.

6. Flexner Abraham. The American College: a Criticism. N.Y. : Century, 1908. P. 374.

7. Harvard University Committee on the Objectives of a General Education in a Free Society. Cambridge, Mass., 1945. P. 191.

8. Leitch Alexander. A Princeton Companion. Prince : Princeton University Press, 1978. P. 374.
9. Myers William Starr. Woodrow Wilson: Some Princeton Memories. Princeton University Press, 1946. P. 83.

10.Perkins H.P. The Impersonal Oxford // Association of American Colleges Bulletin 16, May 1930. P. 47.

11.Pierson George Wilson. Yale: The University College, 1921. 37. New Haven : Yale University Press, 1955. P. 208-216.

12. Slosson Edwin. Great American Universities. N.Y. : Macmillan, 1912. P. 12-18.

13. Twombly John Fogg. College Hall System//Harvard Graduates Magazine, June 1904. P. 585-588.

Журкіна С. В., Коляда І. В. Особливості історично-педагогічних аспектів інституційних трансформацій у ВНЗ США

У статті розглянуто історію впровадження тьюторської системи в американські університети, проаналізовано вплив системи тьюторства Великої Британії на розвиток вищої освіти США. Навчальний метод викладання, коли студентів навчають індивідуально або в дуже малих групах по двоє-троє, розвивався та трансформувався в утвердження тьюторської системи в Оксфордському та Кембриджському університетах. Ця модель викладання існує в Оксфорді з XI століття, а роль тьюторів була задокументована в XV столітmі, коли викладачі в Оксфордському університеті описувалися як відповідальні за поведінку та навчання своїх молодших колее. Необхідно зазначити, що тьюторська система є моделлю взаємодії викладача-тьотора та студентів і має давню історію.

Важливо підкреслити той фракт, що, на відміну від стандартних уявлень викладача, який міг дозволити собі різні види впливу на студента з метою покращення його досягнень (фрізичні або моральні покарання). Тьютор з Оксфорду завжди був на боці студента, він робив усе можливе, щоб підштовхнути студента до пошуку у правильному напрямі, підказати, що і як необхідно зробити для досягнення найкращих результатів у навчанні. Роль тьюьора - це роль викладача-товариша, який має надавати індивідуальні консультації під час регулярних щотижневих зустрічей, а також, що є дуже важливим моментом у тьюторській системі, тьютор і студенти мали змогу зустрічатися і спілкуватися в менш формальній обстановці, що давало змогу зацікавити студентів і допомагало створити дружні відносини між ними.

Протягом останніх років структура та зміст вищої освіти в нашій країні зазнали значних змін, що $\epsilon$ наслідком інтеграції національної освітньої системи в європейський освітній простір. Реформування системи освіти в усіх ії ланках необхідне. Насамперед це стосується вищої освіти, яка має забезпечити суспільство висококваліфрікованими спеціалістами в різних галузях. Справжній науковий і практичний інтерес викликає вивчення досвіду та роботи тьюторів у Великій Британії та США з метою його творчого використання у вищій школі України.

Ключові слова: тьюторська система, тьюторство, тьютор, вища освіта, рефрорми в університетській освіті, метод викладання. 